\title{
HELDER, Herberto. Os passos em volta. Rio de Janeiro: Azougue Editorial, 149 p., 2005.
}

Adelto Gonçalves

Universidade de São Paulo

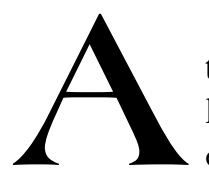

té há pouco tempo, as literaturas portuguesa e brasileira estavam orgulhosamente separadas, podiase dizer, fazendo-se uma referência a um antigo dístico atribuído ao salazarismo. De uns tempos para cá, porém, várias iniciativas têm sido tomadas no âmbito da indústria editorial para que essa distância não seja tão imensa assim.

Com o lançamento de Sonetos (in)temporais, de Cristino Cortes, a Universitária Editora, de Lisboa, em conjunto com o Espaço Coimbra, de São Paulo-SP, abriu uma coleção que não só tem o objetivo imediato de promover a integração cultural entre os dois países como também a divulgação de um conjunto de autores portugueses que se dedicam à criação poética.

Já a editora Escrituras, de São Paulo, com o selo Ponte Velha, voltado exclusivamente para a poesia portuguesa contemporânea, depois de uma primeira fornada que incluiu Nuno Júdice e Pedro Tamen, acaba de colocar ao alcance do leitor brasileiro dois livros de poetas portugueses bastante significativos: António Ramos Rosa, com Animal Olhar, e Ana Hatherly, com A Idade da Escrita e Outros Poemas.

Agora, é a vez da Azougue Editorial, do Rio de Janeiro, que faz chegar ao leitor brasileiro um dos mais singulares trabalhos de Herberto

\footnotetext{
${ }^{1}$ Adelto Gonçalves é doutor em Literatura Portuguesa pela Universidade de São Paulo e autor de Gonzaga, um Poeta do Iluminismo (Rio de Janeiro, Nova Fronteira, 1999), Barcelona Brasileira (Lisboa, Nova Arrancada, 1999; São Paulo, Publisher Brasil, 2002) e Bocage- o Perfil Perdido (Lisboa, Caminho, 2003).
} 
Helder, um dos maiores poetas portugueses do século XX. Considerado um clássico da literatura portuguesa contemporânea, Os passos em volta é uma reunião de pequenas narrativas, muitas delas excertos de prosa poética do mais alto nível. E que vem se juntar a $O$ corpo o luxo a obra, primeira antologia do poeta publicada no Brasil, também pela Iluminuras, em 2000.

Primeiro livro em prosa de Helder, Os passos em volta foi publicado originalmente em 1963, depois que o autor havia feito uma longa viagem pela Europa, passando por Holanda, França, Bélgica e Dinamarca, fato que se reflete em algumas destas narrativas. Foi a viagem de um solitário, alguém pouco identificado que se hospeda em hotéis baratos, perto de rodoviárias ou estações ferroviárias, sem muito compromisso com o bem-estar ou pequenos luxos burgueses.

Em "Escadas e metafísica", lê-se:

Quando voltei a Lisboa já não queria ir para a pensão. Estava farto de empregados do comércio e funcionários públicos. Apetecia-me ficar só. Comer aqui e ali em pequenas restaurantes $\mathrm{e}$, no quarto, à noite, fumar um cigarro à janela, folhear um tratado de arqueologia. Não sentir ninguém nem falar nem me ver obrigado à condescendência ou à fraternidade. Sou um neurótico, vê-se logo. Um egoísta. Deixem-me. Não vou amar o mundo. (...).
Esse é o estilo de Herberto Helder, de frases curtas, cortantes, rápidas, que não deixa o leitor descansar. Os diálogos, quando aparecem, também são breves. Quem escreve é sempre um homem solitário, que olha a vida ao seu redor, sem amores nem vontade de se relacionar com mais intensidade com o próximo, talvez porque já não espere nada da humanidade, mas que, por exemplo, é capaz de oferecer um poema dramático a uma prostituta nas docas de Amsterdam (que não sabia português), como se lê em "Vida e obra de um poeta".

Ler estas narrativas é, portanto, fazer uma viagem sobre o fio cortante que separa a lucidez da loucura. De fato, como escreve nas "orelhas" do livro Eucanaã Ferraz, professor de Literatura Brasileira da Universidade Federal do Rio de Janeiro, esta obra de Helder "põe em cena exatamente a devastadora luta entre estilo e loucura, numa escrita que se dá em ritmo tumultuoso, brutal, nascido por força de uma excitação ininterrupta”.

A mesma indiferença com a vida não se altera nem mesmo numa narrativa como "Trezentos e sessenta graus" em que o protagonista conta o seu retorno, depois de muitos anos, à casa paterna para reencontrar pai e mãe já bastante idosos, "dois velhos estúpidos e inocentes", reconstruindo uma memória em que ternura e rusticidade se mesclam. 
Nascido no Funchal, na Ilha da Madeira, em 1930, Herberto Helder, que mora em Lisboa desde 1945 , estreou em 1958 com o livro $A$ colber na boca. Publicou ainda $O$ bebedor noturno (1968), As magias (1987) e Doze nós numa corda (1997), entre outros. Em 1994, publicou Do mundo, obra pela qual recebeu o Prêmio Pessoa, que preferiu não receber publicamente, sob a alegação de não pretendia romper um comportamento de reclusão voluntária a que se decidira entregar há muito tempo.

Por essa mesma razão, recusou uma premiação do Pen Clube de Portugal em 1982 pelo livro $A$ cabeça entre as mãos e, em 2000, deixou de comparecer ao Salon du Livre, em Paris, para receber outra homenagem. Mas não é só. A grande maioria de seus livros, como observa o editor Sergio Cohen na apresentação, nada traz que nos informe sobre eles, ou a respeito do autor, a não ser o próprio texto.

É uma postura radical, de abominação a tudo o que de fútil a vida pública traz, mas, ao mesmo tempo, como geralmente ocorre, esse comportamento só faz crescer o mistério que cerca o autor, repetindo-se assim o que se dá no Brasil com o contista Dalton Tresivan e na literatura norte-americana com o romancista J. D. Salinger.

\section{Referência Bibliográfica}

Os passos em volta, de Herberto Helder. Rio de Janeiro, Azougue Editorial, 149 págs., 2005, R\$36,00. www.azougue.com.br 